\title{
Potential of goat manure as organic fertilizer in North Sumatera
}

\author{
Siti Fatimah Batubara ${ }^{1, *}$, Agung Budi Santoso ${ }^{1}$, and Khadijah EL Ramija ${ }^{1}$ \\ ${ }^{1}$ Assessment Institute for Agricultural Technology (AIAT) North Sumatera, Indonesia J1. AH. \\ Nasution No 1 B. Medan. 20143
}

\begin{abstract}
The North Sumatera province has the fifth largest goat population in Indonesia after Central, East, Lampung and West Java. Meanwhile, solid and liquid goat manures have great potential as a source of organic fertilizer. Therefore, this study aims to examine the potential of goat manure as a source of organic fertilizer and its role in improving soil quality, growth and crop production. The data were collected from the Central Bureau of Statistics and the results of previous studies. Furthermore, the potential of goat manure was calculated by multiplying the total goat population in North Sumatra by the goat manure production /head/day and converted to one year. The parameter measured was the total goat population in North Sumatera, goat manure production/head/day, and the covered agricultural land area. The results showed that goat manure only fulfilled $3.69 \%$ of the agricultural land area in North Sumatera. In addition, the case study in Deli Serdang District showed that the application of goat manure compost with biourine and balanced inorganic fertilizers increased red chilies' productivity by $46 \%$. Therefore, it was concluded that the potential of goat manure as organic fertilizer is still very low.
\end{abstract}

\section{Introduction}

The goat population in North Sumatera reached 888,598 in 2019 with the largest population being distributed in 5 districts namely Langkat, Deli Serdang, Medan, Simalungun, and Labuhan Batu [1]. Meanwhile, goats not only provide animal protein in the form of meat and milk, but goat manure has great potential as a source of organic fertilizer for agricultural land. Solid goat manure contains $46.58 \%$ organic $\mathrm{C}, 1.34 \% \mathrm{~N}, 0.54 \% \mathrm{P}_{2} \mathrm{O}_{5}$, and $1.56 \% \mathrm{~K}_{2} \mathrm{O}$. After 30 days of composting, the nutrient content reached $2.23 \% \mathrm{~N}, 1.24 \% \mathrm{P}_{2} \mathrm{O}_{5}$, and $3.69 \%$ $\mathrm{K}_{2} \mathrm{O}$ [2]. Besides, goats also produce urine which contains nutrients such as $1.13 \% \mathrm{~N}, 0.05 \%$ $\mathrm{P}_{2} \mathrm{O}_{5}$, and $7.9 \% \mathrm{~K}_{2} \mathrm{O}[3]$.

Agricultural land in Indonesia has experienced a decline in land quality due to inappropriate practices [4] which have decreased productivity. One explanation for this decline in productivity is the over-application of chemical fertilizers and pesticides for a longer period, which damage the quality of land and the environment [5]. Therefore, to support farming, the use of organic fertilizers is very important in an effort to conserve soil

\footnotetext{
${ }^{*}$ Corresponding author : sifa.cha@gmail.com
} 
and plant health. Organic fertilizers improve soil fertility, quality, enhances soil available nutrient as well as bacterial community diversity [6]. Organic farming is an eco-friendly technique, adopted due to the adverse effect of chemical farming. It stimulates and magnifies agro-ecosystem health which includes biodiversity, biological cycle and soil biological activity. This is practiced using agronomic, biological, and mechanical methods rather than synthetic materials to fulfill specific functions within the system [7]. Meanwhile, the need for organic fertilizers is highly dependent on the sources of organic material such as goat manure. Therefore, this study aims to examine the potential of goat manure as a source of organic fertilizer and its role in improving soil quality, growth and crop production in North Sumatera. The Manuscript is based on limited existing data, meanwhile, data were collected from the Central Bureau of Statistics and the results of previous studies. Furthermore, the potential of goat manure was calculated by multiplying the total goat population in North Sumatera by goat manure production /head/day and converted to one year. The parameter measured includes total goat population in North Sumatera, goat manure production/head/day, and the covered agricultural land area.

\section{Potential of goat manure production in North Sumatera}

A previous study reported that goats with weights ranging from $20-40 \mathrm{~kg}$ produced solid and liquid manure up to 0.31 and $2.9 \mathrm{~L} / \mathrm{hd} / \mathrm{d}$ respectively [8]. With a total goat population of 888,598 in 2019 , the mean solid and liquid manure was estimated at 100,544 ton/year and 940,580,000 L/year respectively (Table 1).

Table 1. Potential of goat manure production in North Sumatera

\begin{tabular}{ccccc}
\hline $\begin{array}{c}\text { Population } \\
(\text { head })\end{array}$ & $\begin{array}{c}\text { Solid manure } \\
(\mathrm{kg} / \mathrm{hd} / \mathrm{d})\end{array}$ & $\begin{array}{c}\text { urine } \\
(\mathrm{L} / \mathrm{hd} / \mathrm{d})\end{array}$ & $\begin{array}{c}\text { Solid manure } \\
(\text { ton/year })\end{array}$ & $\begin{array}{c}\text { Liquid manure } \\
(000 . \mathrm{L} / \text { year })\end{array}$ \\
\hline $888598^{*}$ & 0.31 & 2.9 & 100,544 & 940,580 \\
\hline \multicolumn{5}{c}{ Compost } \\
\hline
\end{tabular}

* BPS data 2019

Table 1 shows that the potential solid and liquid manure production of goats was 100,544 ton/year and 940,580,000 L/year respectively. When the solid manure is composted with a weight loss of $33 \%$ [9], then the goat manure compost is 33,179 ton/year. Composting is an effective manure management tool that reduces volume, kills pathogens as well as weed seeds, and also improves soil health and fertility [10].

The addition of manure to the soil is an excellent method to increase soil organic matter which contributes to overall soil health i.e. the soil's ability and sustainability to function as a living ecosystem. Aside from slowly releasing plant nutrients over time, organic matter also improves soil structure and water retaining capacity. Meanwhile, healthier soils improve crop yields, reduce soil loss from both wind and water erosion, and protect water quality by reducing contaminated runoff [11]. Furthermore, the application of organic matter is important because most intensive agricultural land has degraded, and the organic matter content is $<2 \%$ hence, to obtain optimal productivity, C-organic $>2.5 \%$ is needed. The agricultural landmass of North Sumatera in 2019 amounted to 1,359,958 ha consisting of wetland and upland [12]. The general application of manure to wetland (rice) and dry land such as corn, soybeans, and upland rice and was up to 1-2 t ha ${ }^{-1}$. Based on the estimated production, goat manure when applied as organic fertilizer on agricultural land with a mean organic $\mathrm{C}$ content of $<2 \%$ and a recommended 2 ton/ha, is expected to cover an area of $50,272 \mathrm{ha} /$ year or approximately $3.69 \%$ of the agricultural land area in North Sumatera (Table 2). These results indicate that the potential of goat manure is still very low to meet the 
needs of organic fertilizer for agricultural land in North Sumatera. Therefore, the use of manure from other livestock such as cows, chickens and sheep is needed as well as a longterm effort to enlarge livestock and manure production.

Table 2. Potential of goat manure as solid organic fertilizer on agricultural land in North Sumatera

\begin{tabular}{ccccc}
\hline $\begin{array}{c}\text { Manure } \\
\text { Production } \\
\text { (ton/year) }\end{array}$ & $\begin{array}{c}\text { Agricultu } \\
\text { ral land } \\
\text { area (ha) }\end{array}$ & $\begin{array}{c}\text { Dosage of } \\
\text { organic fertilizer } \\
\text { (ton/ha) }\end{array}$ & $\begin{array}{c}\text { Covered } \\
\text { agricultural } \\
\text { land area } \\
\text { (ha/year) }\end{array}$ & $\begin{array}{c}\text { Percentage } \\
(\%)\end{array}$ \\
\hline 100,544 & $1359958^{*}$ & 2 & $50,272.74$ & 3.69 \\
\hline
\end{tabular}

*Pusdatin, 2019

The potential of liquid organic fertilizer production from goats in North Sumatera was $502,724,000 \mathrm{~L} /$ year (Table 1). Meanwhile, goat urine contains macronutrients of $1.13 \% \mathrm{~N}$, $0.05 \% \mathrm{P}_{2} \mathrm{O}_{5}, 7.9 \% \mathrm{~K}_{2} \mathrm{O}$ [3] and other micronutrients. To obtain a better quality of liquid organic fertilizer, goat urine is usually first fermented with microorganisms. The fermentation process uses a biodecomposer, and other ingredients such as coconut water, and livestock rumen [13]. Compared to the solid types, liquid organic fertilizers improves nutrient use efficiency and decrease the risk of nutrient loss. Plants mainly absorb nutrients through the roots, but the leaves also absorb nutrients. Moreover, the special compounds in liquid organic fertilizers, such as chitin, humic and fulvic acids, and other biopolymers, are biostimulants to plants [14]. Liquid organic fertilizers also contain microbes that are good for plants. Soil microorganisms in the rhizosphere play important roles in nutrient cycling and soil structure maintenance, which further promote nutrient cycles and plant growth [15].

Liquid organic fertilizers are applied in small amounts, meanwhile, Indah [16] compared the application of liquid organic fertilizer with a concentration of 1,2 and $3 \mathrm{ml} / \mathrm{L}$ of water on chilies and reported a significant effect on several growth parameters and plant yields with 3 $\mathrm{ml} \mathrm{L}{ }^{-1}$ water as the most optimum concentration.

\section{Potential of goat manure compost and urine for providing nutrients}

Goat manure compost and urine as well as other organic fertilizer materials, contain macronutrients such as $\mathrm{N}, \mathrm{P}, \mathrm{K}, \mathrm{Ca}, \mathrm{Mg}$, and $\mathrm{S}$, as well as micronutrients $\mathrm{Zn}, \mathrm{Cu}, \mathrm{Mo}, \mathrm{Co}, \mathrm{B}$, $\mathrm{Mn}$, and $\mathrm{Fe}$ although in small amounts [17]. In addition, the conversion of manure nutrients into the equivalent inorganic fertilizer refers to the amount of $\mathrm{N}, \mathrm{P}_{2} \mathrm{O}_{5}$, and $\mathrm{K}_{2} \mathrm{O}$ content. Furthermore, urea contains $45-46 \% \mathrm{~N}, \mathrm{SP} 3636 \% \mathrm{P}_{2} \mathrm{O}_{5}$, and $\mathrm{KCl}$ fertilizer contains $45 \% \mathrm{~K}_{2} \mathrm{O}$ [18]. Table 3 shows that goat manure compost in North Sumatera based on 2019 livestock population data has the potential to provide N, P and K nutrients up to 739, 411, and 1,224 ton/year respectively. Meanwhile, goat urine has the potential to provide $\mathrm{N}$ of $10,628,000$ L/year, P 470,000 L/year, and K nutrients 74,305,000 L/year.

When converted to the inorganic fertilizer equivalents, the nutrient content of compost is equivalent to Urea 1,608 ton/year, SP36 1,142 ton/year, and $\mathrm{KCl}$ 2,720 ton/year, while the nutrient content of goat urine is equivalent to Urea 23,105 ton/year, SP36 1,306 ton/year, and $\mathrm{KCl} 165,124$ ton/year. 
Table 3. Contribution of compost and urine nutrient content equivalent to inorganic fertilizers

\begin{tabular}{|c|c|c|c|c|c|c|}
\hline & \multicolumn{3}{|c|}{ compost (ton/year) } & \multicolumn{3}{|c|}{ urine (000. L/year) } \\
\hline $\begin{array}{l}\text { Nutrient } \\
\text { content }(\%)\end{array}$ & $\mathrm{N}(2.23)$ & $\mathrm{P}(1.24)$ & K (3.69) & $\mathrm{N}(1.13)$ & $\mathrm{P}(0.05)$ & K (7.9) \\
\hline $\begin{array}{l}\text { Nutrient } \\
\text { supply } \\
\text { potential }\end{array}$ & 739 & 411 & 1,224 & 10,628 & 470 & 74,305 \\
\hline $\begin{array}{l}\text { Nutrient } \\
\text { content } \\
\text { equivalent } \\
\text { to } \\
\text { inorganic } \\
\text { fertilizers } \\
\text { (ton) }\end{array}$ & $\begin{array}{l}\text { Urea } \\
(46 \% \mathrm{~N})\end{array}$ & $\begin{array}{l}\mathrm{SP} 36 \\
\left(36 \% \mathrm{P}_{2} \mathrm{O}_{5}\right)\end{array}$ & $\begin{array}{l}\mathrm{KCl} \\
\left(60 \% \mathrm{~K}_{2} \mathrm{O}\right)\end{array}$ & $\begin{array}{l}\text { Urea } \\
(46 \% \mathrm{~N})\end{array}$ & $\begin{array}{l}\mathrm{SP} 36 \\
\left(36 \% \mathrm{P}_{2} \mathrm{O}_{5}\right)\end{array}$ & $\begin{array}{l}\mathrm{KCl} \\
\left(45 \% \mathrm{~K}_{2} \mathrm{O}\right)\end{array}$ \\
\hline
\end{tabular}

Economically, goat manure compost reaches 18,527,400,000 IDR/year while goat urine 234,885,450 IDR/year.

Table 4. Economic value of compost and goat urine

\begin{tabular}{lccll}
\hline $\begin{array}{c}\text { Type organic } \\
\text { fertilizer }\end{array}$ & $\begin{array}{c}\text { Type of } \\
\text { inorganic } \\
\text { fertilizer }\end{array}$ & $\begin{array}{c}\text { Nutrient content } \\
\text { equivalent to } \\
\text { inorganic fertilizer } \\
\text { (kg/year) }\end{array}$ & Price/kg & $\begin{array}{c}\text { Total }(000 . \\
\text { IDR/year) }\end{array}$ \\
\hline Compost & Urea & $1,608,000$ & 2,250 (subsidize) & $3,618,000$ \\
& SP36 & $1,142,000$ & 2,400 (subsidize) & $2,740,800$ \\
KCl & $2,720,000$ & 9,000 (nonsubsidize) & $24,480,000$ \\
& & & Total & $30,838,800$ \\
Urine & Urea & $23,105,000$ & 2,250 (subsidize) & $51,986,250$ \\
& SP36 & $1,306,000$ & 2,400 (subsidize) & $3,134,400$ \\
& KCl & $165,124,000$ & 9,000 (subsidize) & $1,486,116,000$ \\
& & & Total & $1,541,236,650$ \\
\hline
\end{tabular}

\section{A case study of compost and biourine application on red Chilies in Deli Serdang District, North Sumatera}

The use of goat manure compost and biourine on red chilies in Deli Serdang district, North Sumatera with dosage treatment of organic and inorganic fertilizers according to farmers' application showed an increase in the yield up to $46 \%$ (Table 5).

Furthermore, the use of organic inputs such as crop residues, manures and compost have great potential to improve soil productivity and crop yield through the improvement of the physical, chemical and microbiological properties of the soil as well as nutrient supply. In addition, compost adds a balance of nutrients, provides valuable organic material to the soil, and also increases soil fertility as well as crop yields. The application of compost to 5 and 10 ton $\mathrm{ha}^{-1}$ and humic acid produced maximum plant height, length, 100-grain weight, grain, straw, and biological yield, grain protein concentration (\%) and grain $\mathrm{K}$ content (\%) of maize varieties [19]. 
Table 5. Productivity of red chilies with compost and biourine treatment in Deli Serdang District, North Sumatera

\begin{tabular}{lcc}
\hline Commodity & \multicolumn{3}{c}{ Red Chili } \\
\hline Treatment & \multicolumn{1}{c}{$\begin{array}{c}\text { Farmer } \\
\text { ton/ha compost, } \\
\text { inorganic fertilizer based } \\
\text { on farmer's }\end{array}$} & $\begin{array}{l}10 \text { ton/ha compost, } 10 \mathrm{ml} / \mathrm{L} \\
\text { biourine, organic fertilizer } \\
\text { based on recommendation }\end{array}$ \\
$\begin{array}{l}\text { Mean Productivity } \\
\text { (ton/ha) }\end{array}$ & 9.4 & 17.4 \\
Increase productivity & & $46 \%$ \\
\hline
\end{tabular}

\section{Conclusion}

Compost production from solid goat manure only fulfills $3.69 \%$ of the agricultural land area in North Sumatera. Meanwhile, the potential of goat urine to meet organic fertilizer needs is greater compared to compost as indicated in the production and nutrients contribution. Furthermore, the contribution of nutrients equivalent to inorganic fertilizers in solid compost and goat urine is approximately $30,838,800,000$ and 1,541,236,650,000 (year ${ }^{-1}$ ) respectively. This suggests that organic fertilizer from solid and liquid goat manure is applicable as an alternative to reduce the use of inorganic fertilizers.

\section{References}

1. BPS. Sumatera Utara in Figure 2020 (Badan Pusat Statistik Sumatera Utara., 2020)

2. L. Trivana, and A. Y. Pradana, J. Sain. Vet. 35, 1 (2017)

3. B. Alvi, M. Ariyanti and Y. Maxiselly, Jurnal Kultivasi 17, 2 (2018)

4. Wahyunto and A. Dariah. Land Resource Journal. 8, 2, 81-93 (2014)

5. Kementerian Pertanian. Road Map Swasembada Beras Berkelanjutan, Tahun 20102014 (Direktorat Jenderal Tanaman Pangan, Jakarta, 2010)

6. L. Shang, L. Wan, X. Zhou, S. Li, X. Li. PLoS ONE 15, 10 (2020)

7. N. Nandan and A. Gami. J. of Agrotech. and Nat. Res. Man. 2, 1 (2015)

8. J. A. Ogejo, S. Wildeus, P. Knight, R. B. Wilke, American Soc. of Agr. and Bio. Eng. 26, 6, 1061-1065 (2010). ISSN 0883-8542

9. P. Widiyaningrum and Lisdiana, Rekayasa 13, 2 (2015)

10. C. Augustin and S. Rahman. Composting Animal Manures: A Guide to the Process and Management of Animal Manure Compost (NDSU Extension Service, North Dakota State University Fargo, North Dakota, 2016)

11. US Environmental Protection Agency. National Cattlemen's Beef Association U.S. Poultry \& Egg Association United Egg Producers National Pork Producers Council National Milk Producers Federation (https://www.epa.gov), (2015)

12. Pusat Data dan Sistem Informasi Pertanian. Statistics of Agricultural Land 2015-2019. (Sekretariat Jenderal-Kementerian Pertanian, 2020)

13. E. Kurniawan, Z. Ginting., and P. Nurjannah. Pemanfaatan Urin Kambing pada Pembuatan Pupuk Organik Cair Terhadap Kualitas Unsur Hara Makro (NPK). (umj.ac.id/index.php/semnastek), (2017). ISSN: 2407-1846

14. P. Toonsiri, S. J. Del Grosso, A. Sukor, J. G. Davis, J. Environ. Qual. 45, 1812-1821. (2016) 
15. M. Saleem, L. A. Moe, Trends Biotechnol. 32, 10, 529-537 (2014)

16. Makmur, Jurnal Galung Tropika 7, 1, 1-10 (2018) ISSN: 24076279

17. I. Juarsah. Pemanfaatan Pupuk Organik untuk Pertanian Organik dan Lingkungan Berkelanjutan, in Proceedings of the Seminar Nasional Pertanian Organik. 127-136. (2014)

18. I. Purwanto, E. Suaheti, and E. Sumantri, Petunjuk Teknis Pelaksanaan Penelitian Kesuburan Tanah, Menghitung Kebutuhan Pupuk untuk Percobaan Kesuburan Tanah (Badan Penelitian dan Pengembangan Pertanian, Kementerian Pertanian, 2014), pp. 91-105.

19. E. E. Kandil, N. R. Abdesalam, M. A. Mansour, H. M. Ali, and M. H. Siddiqui, Potential of Organic Manure and Potassium Forms on Maize (Zea Mays L.) Growth and Production, Scientific Reports, (www.nature.com), (2020) 